\title{
Joint IODP/ICDP Scientific Drilling of the Chicxulub Impact Crater
}

\author{
by Jo Morgan, Gail Christeson, Sean Gulick, Richard Grieve, Jaime Urrutia, \\ Penny Barton, Mario Rebolledo, and Jay Melosh
}

Impacts of asteroids and comets on planets are fundamental processes in the solar system. Relatively few pristine craters are preserved on the Earth because of the vigorous endogenic geologic processes that affect its surface. Nonetheless, only terrestrial craters can provide us with direct observations on the subsurface structure of impact craters, the dynamics of crater formation, and the effect on the planetary environment as preserved in the geological record.

The Chicxulub impact crater in Mexico (Fig. 1) is unique in the terrestrial impact record. Its association with the Cretaceous-Paleocene (K-P) mass extinction has generated great interest, but the precise environmental effects and associated extinction mechanisms remain a matter of some debate over several decades. Chicxulub is also the best preserved large impact crater on Earth and is the only known terrestrial impact structure with a demonstrable topographic peak ring (Figs. 2 and 3). Peak rings are common features of large craters on the terrestrial planets yet their process of

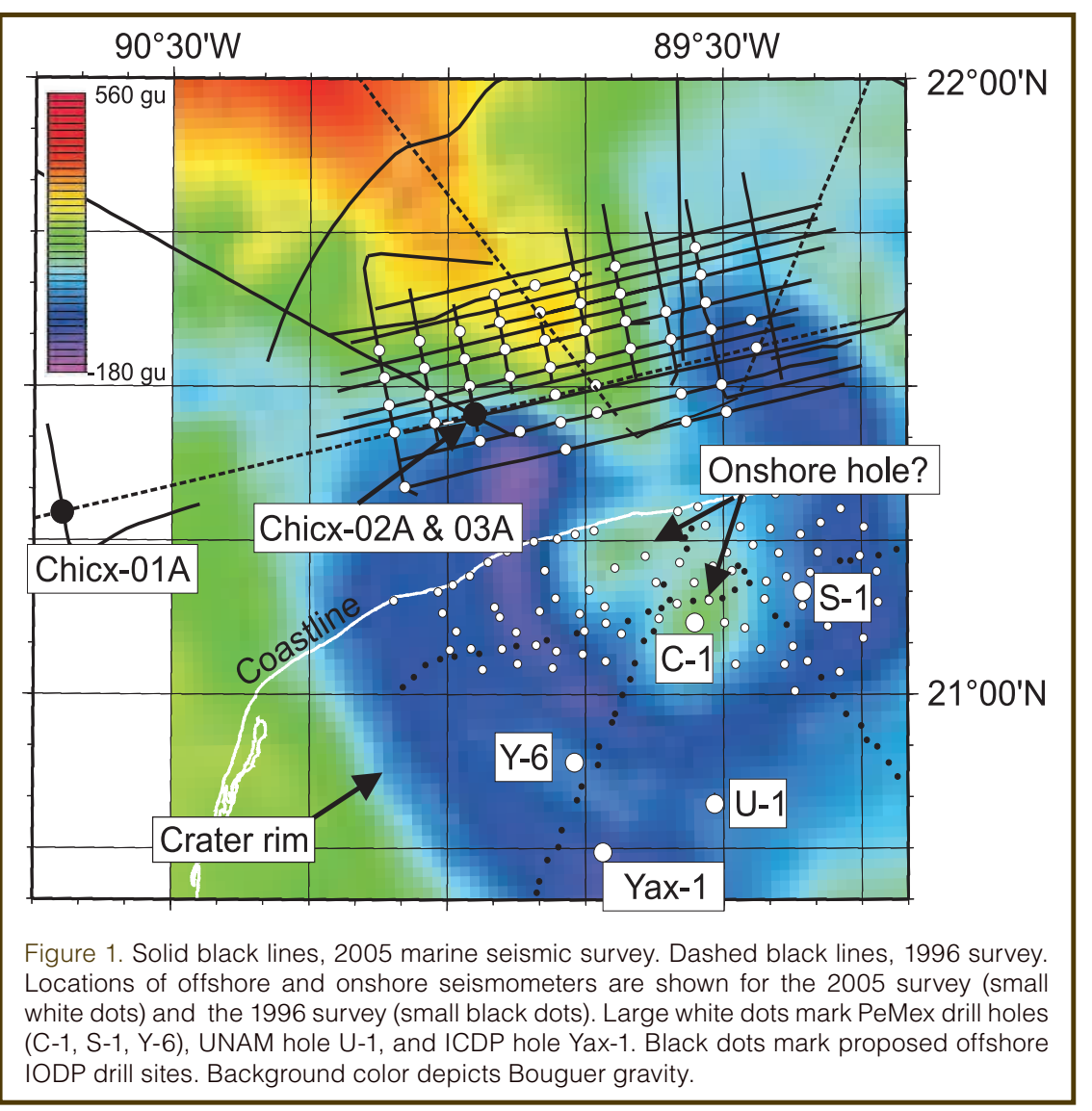

formation is poorly understood. At all other large terrestrial craters, erosion and/or tectonic deformation have removed the evidence of a peak ring, should one have existed. Chicxulub is, thus, the only crater where the peak ring can be imaged and sampled.

The Chicxulub structure, partly located onshore and partly offshore, is buried below post-impact sediments (Figs. 1 and 2). Thus, while geophysical imaging of the structure is possible (Fig.3), sampling of the structure can only be done through drilling and coring. Onshore there are several deep, but mainly uncored, industry wells (S-1, C-1 and Y6 in Fig. 1), a number of shallow holes drilled by Universidad Nacional Autonóma de México (U-1), and one deep International Continental Scientific Drilling Program (ICDP) hole, Yaxcopoil-1 (Yax-1), drilled in 2002. No holes have yet been drilled offshore (Figs. 1 and 2).

A workshop on future scientific drilling of the Chicxulub impact crater was held at GeoForschungsZentrum Potsdam (GFZ), Germany on 11-12 September 2006. The workshop was sponsored by the Integrated Ocean Drilling Program (IODP) and ICDP. Fifty scientists from eleven countries attended the workshop. During the first day keynote speakers outlined the current state-of-knowledge of large impact craters (Chicxulub in particular), reviewed results from previous drilling at Chicxulub, and showed new seismic data (Figs. 1 and 3) that were acquired across the crater in 2005 (Morgan et al., 2005). On the second day potential new drill sites, their scientific priorities, and associated logistics were discussed.

Two holes were identified as critical to advancing the understanding of cratering mechanisms: i) one hole through the crater's topographic peak ring (offshore location), and ii) a second well near the crater center passing through the entire sequence of impactites, particularly the impact melt sheet, and into the uplifted crust in the center of the crater (onshore location). There was unanimous support for a joint IODP- 


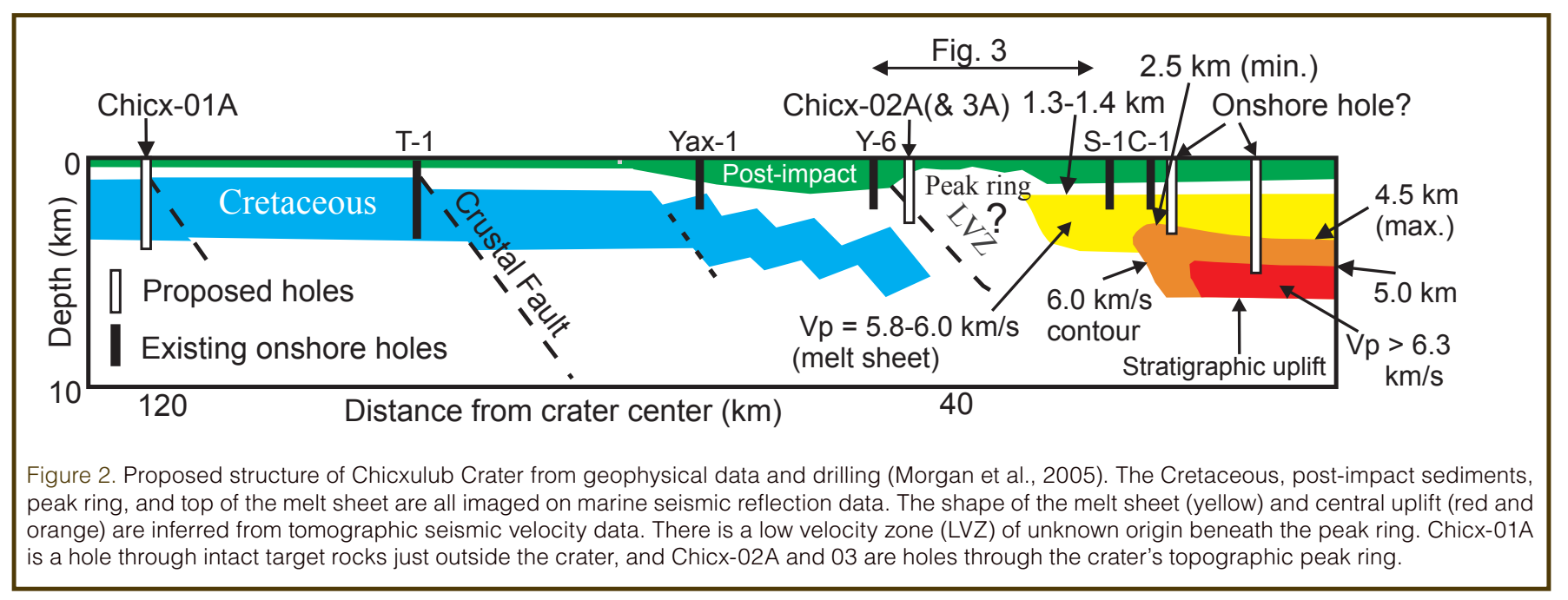

ICDP planning and execution of the entire drilling efforts, including sample and data handling.

\section{Offshore Drilling of the Peak Ring}

Workshop participants were universally enthusiastic about drilling through the peak ring and underlying dipping reflectors. The expected lithologies of the drill hole include $\sim 700 \mathrm{~m}$ of post-impact fill, and $2.3 \mathrm{~km}$ of peak-ring forming material (suevitic breccia, megabreccia, and/or fractured basement). From $\sim 2.35 \mathrm{~km}$ depth this hole will sample a suite of dipping reflectors that can be traced from the outer edge of the peak ring to the inner edge of the slumped blocks (Figs. 2 and 3). This hole will determine the fundamental character of the lithologies above and below the dipping reflectors, the physical state of the material, and the cause of the reflectivity. We will use these data to discriminate between competing models of peak ring formation. If the peak ring material here has been overturned, as predicted by some numerical models, these reflectors may represent the boundary between outwardly collapsed central uplift and inwardly collapsed transient crater rim.

The lithological, geochemical, and structural characteristics of these Chicxulub wells will provide the first data set of this kind from the Earth, or indeed from anywhere within the solar system.

A discussion group on hydrothermal processes recognized that recent studies at large terrestrial impact craters indicate that significant hydrothermal activity is likely to occur within the peak ring. The drill core can provide information on the temperatures and composition of hydrothermal fluids and on the longevity of the system. Hydrothermal activity could also lead to a niche for hyperthermophilic bacteria with impact-induced porosity and translucence supporting colonization by cyanobacteria (Cockell et al., 2002). These studies may therefore help understanding the development of early life on Earth and possibly Mars, where impacts were more frequent in early Archean time.
Chicx-03A (Figs. 2 and 3) was chosen as the best location for a peak ring drill site. A site further towards the crater center has the potential to provide more information about the peak-ring forming material but would not reach the dipping reflectors. Conversely, a site further out from the center would reach the dipping reflectors at a shallower depth but would not necessarily sample 'typical' peak ring material.

\section{Onshore Drilling of the Melt Sheet and Suevite}

Another critical target identified by the workshop is an onshore hole near the crater center (Figs. 1 and 2). Scientific targets of this hole would be to examine the entire suevite and impact melt rock sequence, variations in the clasts with respect to amount, composition, and degree of shock in both of these impactite layers; to investigate if the melt sheet is differentiated; to search for a projectile component and its variation with depth; and to document the lithologies above and below the melt sheet, including any secondary mineralization due to hydrothermal activity. Physical properties measured within the hole, together with seismic, magnetic, and gravity data, will allow us to produce a well-constrained 3-D geophysical model of the crater, including an improved estimate of total melt volume, which is intimately connected to impact energy.

Participants agreed that this hole should be located to recover as thick a sequence of melt as possible, but also should penetrate at least $200 \mathrm{~m}$ into the central uplift. According to our tomographic velocity model (Fig. 2), a hole near the crater center would reach the uplifted crust at $\sim 4.5 \mathrm{~km}$ depth and might be prohibitively expensive. Consequently, a more feasible location for this hole is close to the onshore uncored industry well C-1 (Fig. 1), where the melt sheet was found at a depth of $\sim 1300 \mathrm{~m}$, based on well cuttings, and where the central uplift is between 2.5 and $3.3 \mathrm{~km}$ subsurface. 


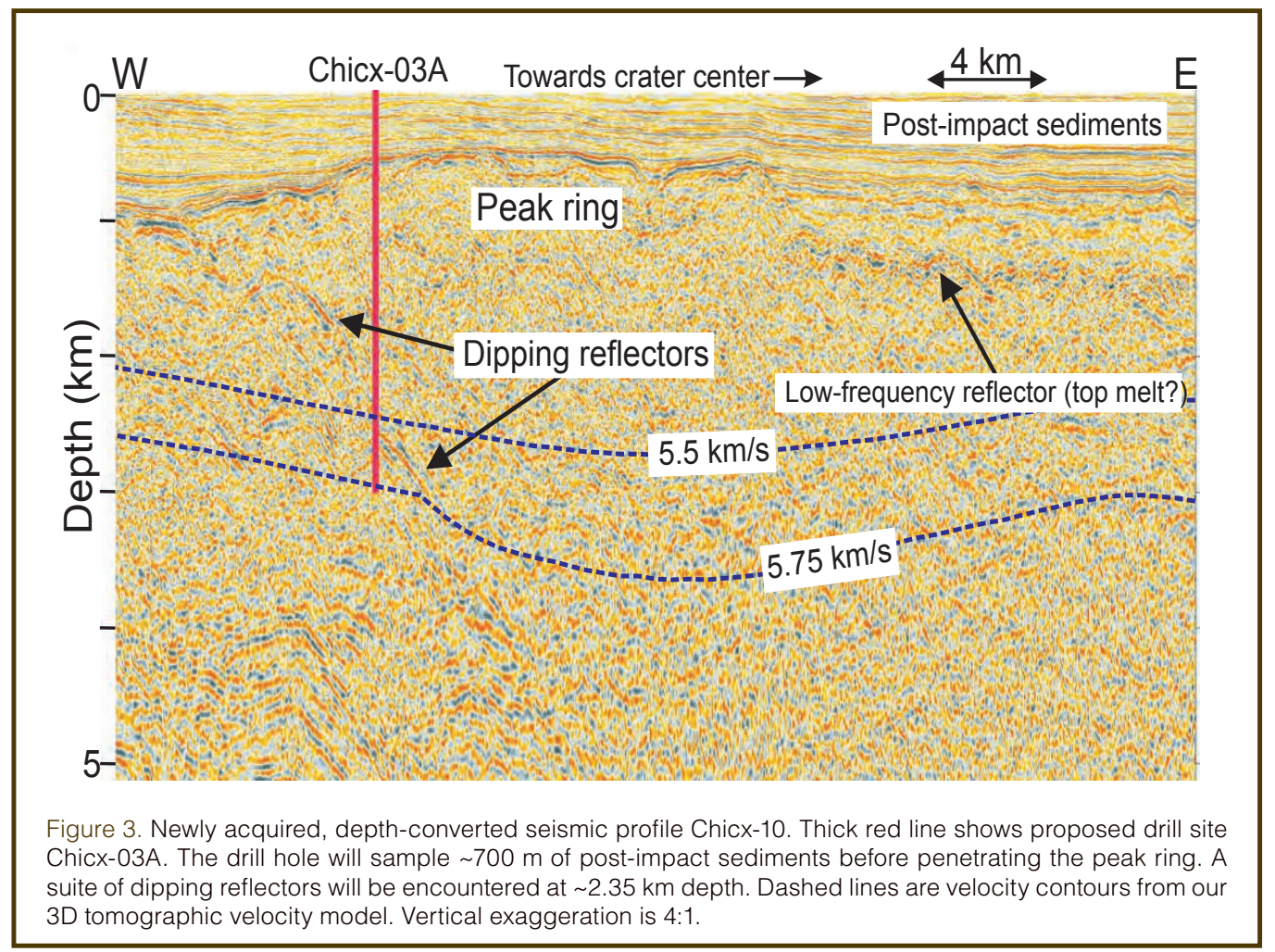

Both the onshore and offshore holes will penetrate through post-impact sediments, which are $\sim 700 \mathrm{~m}$ thick in Chicx-03A and $1100 \mathrm{~m}$ close to drill hole C-1, and which are likely to include impact-generated tsunami deposits, the biotic recovery with time, long-term hydrothermal activity, mineralization, and the post-impact paleoceanographic record.

The workshop participants concluded that Chicxulub crater is a unique natural laboratory that assumes a crucial role in providing information on the impact cratering process, including a possible link to niche creation for early life, and the global effect of a large-scale impact event. They also agreed that its further investigation should be pursued in a coordinated joint effort by the IODP and the ICDP.

\section{Acknowledgments}

The workshop was jointly sponsored by the International Continental Scientific Drilling Program (ICDP) and the Integrated Ocean Drilling Program Management International, Inc. (IODP-MI). The Joint Oceanographic Institutions (JOI) and Natural Environment Research Council (NERC) provided travel support for some U.S. and U.K. participants.

\section{References}

Cockell, C.S., Lee, P., Osinski, G.R., Horneck, G., and Broady, P., 2002. Impact-induced microbial endolithic habitats. Meteorit. Planet. Sci., 37: 1287-1298.

Morgan, J., Warner, M., Urrutia-Fucugauchi, J., Gulick, S., Christeson, G., Barton, P., Rebolledo-Vieyra, M., and Melosh, J., 2005. Chicxulub crater seismic survey prepares way for future drilling. EOS, Trans., Am. Geophys. Union, 86:325-328, ISSN: 0096-3941.

\section{Authors}

Joanna Morgan, Department of Earth Science and Engineering, Imperial College London, South Kensington Campus, London SW7 2AZ, U.K., E-mail: j.v.morgan@ imperial.ac.uk

Gail Christeson, University of Texas Institute for Geophysics, J.J. Pickle Research Campus, Mail Code R2200, 10100 Burnet Rd, Austin, Texas 78759-8500, U.S.A.

Sean Gulick, University of Texas Institute for Geophysics, J.J. Pickle Research Campus, Mail Code R2200, 10100 Burnet Rd, Austin, Texas 78759-8500, U.S.A.

Richard Grieve, Natural Resources Canada, 580 Booth Street, 14th Floor, Room B4-4, Ottawa, Ontario K1A 0E4, Canada

Jaime Urrutia, Instituto de Geofisica, Universidad Nacional Autónoma de México, Ciudad Universitaria, Del Coyoacán México D.F., C.P. 04510

Penny Barton, Department of Earth Sciences, University of Cambridge, Madingley Rise, Cambridge CB3 0EZ, U.K.

Mario Rebolledo, Centro de Investigación Cientifica de Yucatán, Calle 8 \# 39, Cancun, México 77500

Jay Melosh, Lunar and Planetary Laboratory, University of Arizona, Tuscon, Ariz. 85721, U.S.A.

\section{Related Web Link}

http://chicxulub.icdp-online.de/ 